\title{
RADIOCARBON DATES FROM THE HIGHLAND JAR AND COFFIN BURIAL SITE OF PHNOM KHNANG PEUNG, CARDAMOM MOUNTAINS, CAMBODIA
}

\begin{abstract}
Nancy Beavan ${ }^{1}$ - Derek Hamilton ${ }^{2} \cdot$ Tep Sokha $^{3} \cdot$ Kerry Sayle $^{2}$
ABSTRACT. The Cardamom Mountain Jar and Coffin burial site of Phnom Khnang Peung is the most extensive example of the distinctive burial ritual first reported by Beavan et al. (2012a). The 40 intact Mae Nam Noi and late Angkorian-era ceramic jars used as burial vessels held a total of up to 152 individuals, representing the largest corpus of skeletal remains of any of the 10 known Jar and Coffin burial sites that have been discovered in the eastern ranges of the Cardamom Mountains of Cambodia. We report here on the radiocarbon dating of this site and notable burial phenomena, using a Bayesian approach to model the start and end date of activity as well as its overall span. The results of the dating and Bayesian analyses indicate that the Phnom Khnang Peung site's earliest burials began cal AD 1420-1440 (95\% probability). Interestingly, the concentration of burial activity spans only $15-45$ years (95\% probability), despite the large number of inhumations at the site. The ${ }^{14} \mathrm{C}$ chronology presented for the site places the Highland burial ritual coincident with a period of economic, political, and societal transformations in the lowland Angkorian polity, but the unique burial practice and trade relationships evidenced by the burial goods and maritime trade ware ceramics employed in the burial ritual suggest these Highland people were a culture apart from Angkorian cultural influences.
\end{abstract}

\section{INTRODUCTION}

Beavan et al. (2012a) first reported on the Jar and Coffin burial sites of the Cardamom Mountains, southern Cambodia. There are 10 burial sites that have been located since 2001 and are shown in Figure 1. These sites consist of whole-log coffins and 15th-17th century AD maritime trade ware storage jars placed upon natural rock ledges, at elevations of between 147 to $700 \mathrm{~m}$ above sea level (asl). Both the jars and the coffins hold secondary burials of human bone, which are an intentional reburial of human remains after a primary burial or other form of excarnation (Schroeder 2001:77). The Cardamom Jar and Coffin burial vessels often contain multiple interred individuals of as many as six co-mingled human burials, but the manner in which the primary excarnation of the bodies was undertaken in the Cardamom sites is not yet known.

Burials within each ceramic jar or hand-hewn wooden coffin are always accompanied by simple copper finger rings (first reported in the sites by Beavan et al. 2012a). These rings have copper alloy profiles, some of which are consistent with central Lao copper production and others for which there is no current match with known copper profiles in Southeast Asia. A paper on the analysis of the metal finds is currently being drafted.

Other grave goods are varied sorts of colored glass beads. Compositional analysis using laser ablationinductively coupled plasma-mass spectrometry (LA-ICP-MS) identified different glass recipes that reflect different manufacturing and exchange network sources (A K Carter and N Beavan, unpublished data). These include a high-alumina mineral soda glass group (suggesting connections with western India), coiled-lead potash glass beads (associated with Chinese manufacturing), a smaller group of beads of vegetable soda glass group with a compositional similarity to artifacts found in Sumatra, and a small number of beads that may reflect an unknown subgroup of high-alumina mineral soda glass (A K Carter and N Beavan, unpublished data). The presence of the rings and beads indicate the Highlanders maintained exchange relationships with lowland trade networks.

The first radiocarbon dates from four of the known burial sites placed this Highland mortuary practice in the Late- to Post-Angkorian period, 15th-17th centuries AD (Beavan et al. 2012a). The Highland burial practice is unique when compared to the lowland mortuary practices of the peri-

1. Department of Anatomy, Otago School of Medical Sciences, PO Box 913, Dunedin 9054, New Zealand. Corresponding author. Email: nancy.beavan@anatomy.otago.ac.nz.

2. SUERC Radiocarbon Dating Laboratory, East Kilbride, Scotland.

3. Faculty of Archaeology, Royal University of Fine Arts, Phnom Penh, Cambodia. 
od. While the secondary burial of bone in exposed jars and coffins is recorded in diverse cultures throughout mainland and island Southeast Asia (Fox 1970; Kurjack and Sheldon 1971; Harrison 1974; Sayavongkhamdy and Bellwood 2000; Chia and Koon 2003; Bellwood 2007), lowland Khmer-related practices from about $300 \mathrm{BC}$ to the mid-1400s AD included inhumations, exposure for natural decay, disposal in rivers, and cremation (Pelliot 1903; Stark 2001; Higham 2002; Harris 2007).

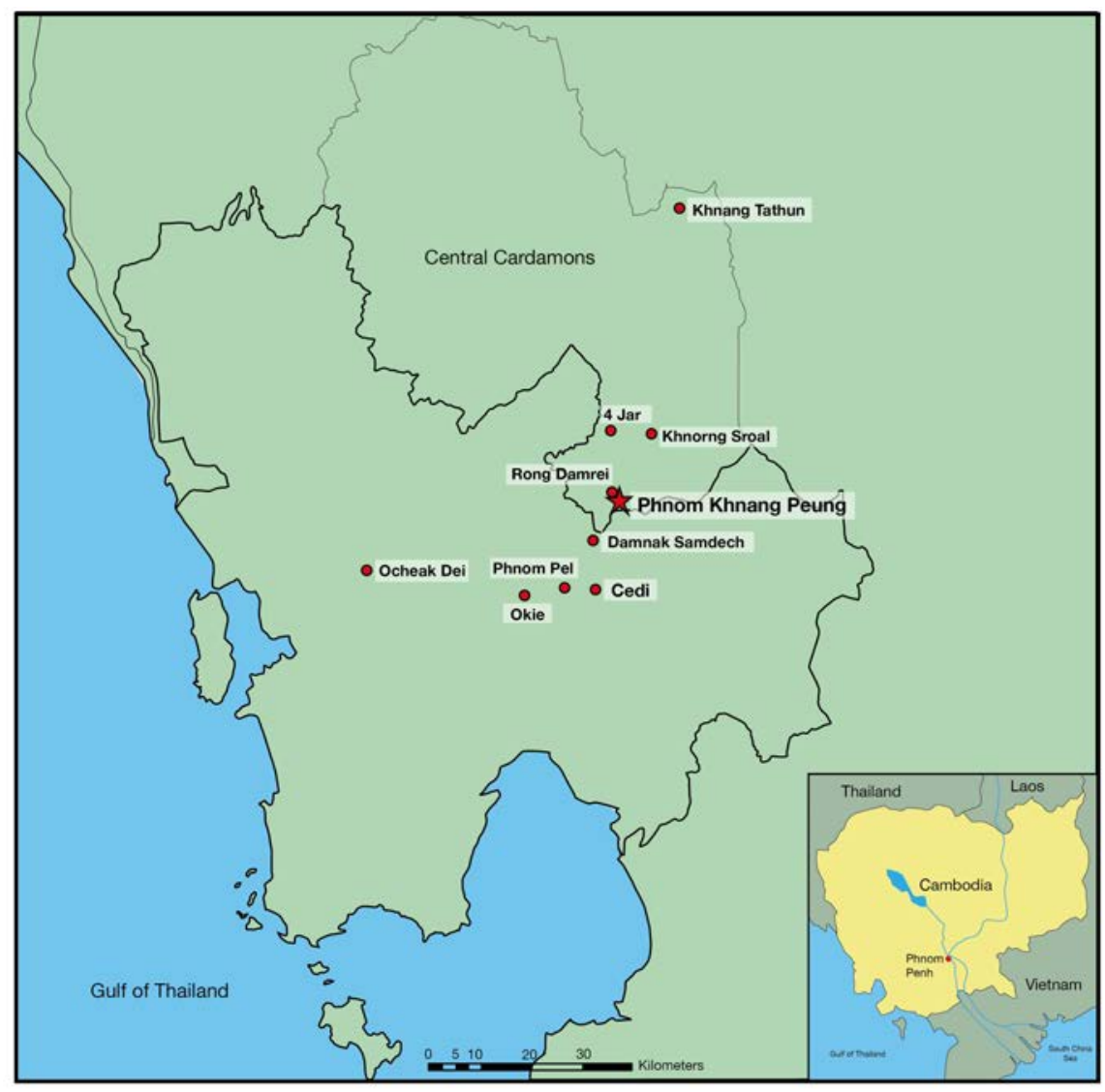

Figure 1 Map of the 12 Highland Jar and Coffin Burial sites. Phnom Khnang Peung denoted with a star.

A corpus of ${ }^{14} \mathrm{C}$ results is presented here from Phnom Khnang Peung, the most significant site so far reported in the "Living in the Shadow of Angkor" project, which aims to establish a chronology for the Highland burial sites. These results have been analyzed using a Bayesian approach (Buck et al. 1996) to model the start and end date of activity, as well as the overall span. The Bayesian approach allows for the production of more realistic and precise chronologies by utilizing the archaeological information, such as phasing and stratigraphy, and accounting for the statistical scatter inherent in both the ${ }^{14} \mathrm{C}$ dating method and calibration (Bayliss 2009). The methodology is interpretative, but also explicit with regard to the data that is input. As such, the estimates can change as researchers add new data or choose to model the current data in different ways. For archaeologists, using this approach provides a robust means through which new questions can be asked about the timing and temporality of archaeological material. 


\section{Phnom Khnang Peung Site}

Phnom Khnang Peung (KPP) is situated close to the provincial borders of Koh Kong and Khampong Speau in southern Cambodia (UTM 48P $0353517 \mathrm{E} ; 1279416, \pm 5 \mathrm{~m}$, base datum WGRS60; Figure 1). The site sits at $633 \pm 5 \mathrm{~m}$ asl in a sheer sandstone cliff face and consists of a natural rock ledge $9.9 \mathrm{~m}$ long and a maximum of $3.09 \mathrm{~m}$ deep, which was divided into six sections for analysis (A1/2, B1/2, C, D; Figure 2a). The ledge held some 40 intact ceramic storage jars containing human remains, two intact hand-hewn coffins and coffin lids, and fragments of additional coffins. The ledge also had a cavity in the back wall of the A1 section in which a "pod"-shaped coffin and additional coffin fragments had been placed (Figure 2a).
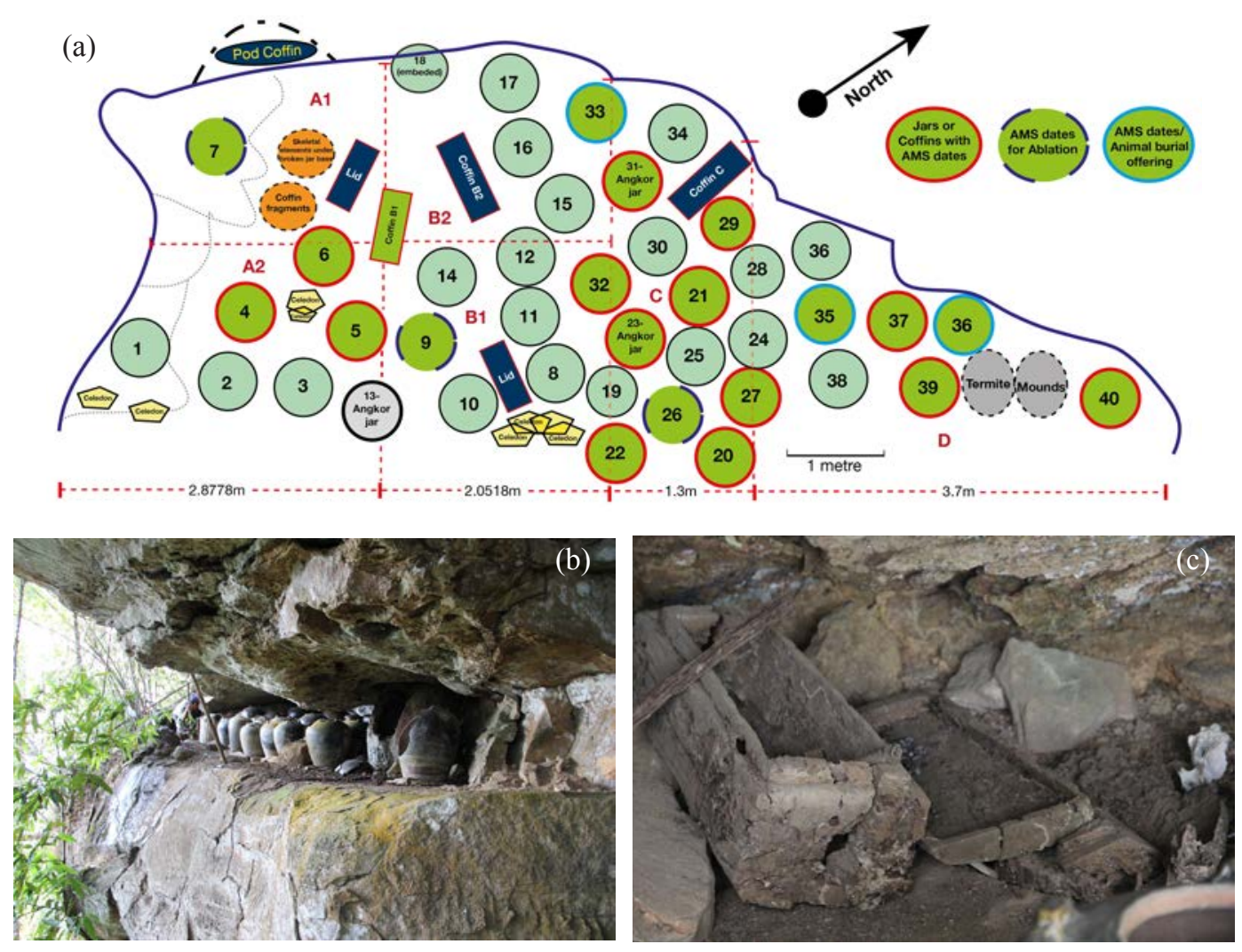

Figure 2 (a) Layout of the burial jars and coffins on the Phnom Khnang Peung rock ledge. The map legend denotes those burial jars or coffins with ${ }^{14} \mathrm{C}$ dates that are presented in this paper. (b) The burial jars in situ on the ledge. (c) Coffin 1, Section $\mathrm{C}$, with its lid set to one side.

Of the intact ceramic storage jars, 37 were 14th-16th century AD, Mae Nam Noi-style ceramics from the Singburi/Maenam Noi kilns of Thailand (Brown 2004; Grave and Maccheroni 2009:201, Figure 5a). Additional ceramic wares included 15th-16th century AD Thai Sawankhalok celadon bowls and Sisatchanalai dishes (Brown 1977, 2004; Grave and Maccheroni 2009), fragments of porcelain that are possibly Chinese, smaller Mae Nam Noi stoneware water jars and earthenware cooking pots, and numerous shards from broken storage jars; a complete assessment of the ceramics of the Jar and Coffin Burial sites is forthcoming. The Mae Nam Noi burial jars and other ceramics found in the KPP site are also represented in maritime trade cargoes of the 14th century onward in the Gulf of Thailand (Brown 1977; Beavan et al. 2012b; Tep 2014), and the presence of significant 
numbers of Mae Nam Noi and other maritime trade ceramics in the Jar Burial sites may be indicative of a previously unsuspected trade relationship between the Cardamom highland people and contemporaneous coastal shipping routes (Beavan et al. 2012a,b). An additional three large ceramic storage jars are "Angkorian" (Figure 5b) whose possible sources are discussed later in this paper. The jars are likely from inland kiln sites that contributed to ceramic production and distribution within the Angkor kingdom from the 11th to 13th centuries AD (Groslier 1981).

\section{METHODS}

A total of 53 samples, comprising 49 human and 4 animal bones from pig (Sus, possibly scrofa sp., which were associated with specific burial jars) were submitted from the site of KPP for ${ }^{14} \mathrm{C}$ and stable isotope analyses (Table 1). Additional human burials and associated pig and dog burial offerings are now being processed. Morphological techniques such as visual pair matching, articulation, and the process of elimination (L'Abbe 2005) were used to determine the minimum number of individuals for the site due to the co-mingled nature of the jar burials. Skulls were the preferred element for sampling. In the instance where an infant had no cranial material present, rib bones were sampled. Age and sex estimation of the human remains was performed using standard methods (Buikstra and Ubelaker 1994).

The bone samples were mechanically cleaned with a small drill to remove degraded surface material and any adhering soil. Bone samples were then placed in clean plastic $50-\mathrm{mL}$ vials for chemical demineralization using a modified Longin (1971) method with $0.5 \mathrm{M} \mathrm{HCl}$. The insoluble collagen was isolated by centrifuging and decanting of the supernatant acid, then rinsed to neutral by topping each vial with Milli- $\mathrm{Q}^{\mathrm{TM}}$ deionized water, centrifuging, and decanting supernatant in repeated washes. The insoluble collagen was gelatinized with $0.01 \mathrm{M} \mathrm{HCl}$ at $60^{\circ} \mathrm{C}$ for $24 \mathrm{hr}$, and then double-filtered through Whatman ${ }^{\mathrm{TM}} \mathrm{GF} / \mathrm{C}$ and $0.45-\mu \mathrm{m}$ Acrodisc ${ }^{\mathrm{TM}}$ filters. The filtered gelatin was lyophilized to obtain gelatin yields relative to starting weight of physically cleaned bone.

The samples of freeze-dried collagen were submitted for ${ }^{14} \mathrm{C}$ analyses to the Scottish Universities Environmental Research Centre (SUERC), East Kilbride. The collagen was combusted following Vandeputte et al. (1986) and graphitized and measured by accelerator mass spectrometry (AMS) as described by Naysmith et al. (2010).

Stable isotope analyses were performed for each of the individuals ${ }^{14} \mathrm{C}$ dated. Carbon $\left(\delta^{13} \mathrm{C}, \% \mathrm{C}\right)$ and nitrogen $\left(\delta^{15} \mathrm{~N}, \% \mathrm{~N}\right)$ were analyzed at SUERC using a Thermo Scientific Delta V Advantage continuous-flow isotope ratio mass spectrometer (CF-IRMS) coupled via a Thermo Scientific ConfloIV to a Costech ECS 4010 elemental analyzer (EA) fitted with a pneumatic autosampler. Bone collagen samples were weighed into tin capsules $(\sim 600 \mu \mathrm{g})$ and combusted in the presence of oxygen in a single reactor containing tungstic oxide and copper wires at $1020^{\circ} \mathrm{C}$ to produce $\mathrm{N}_{2}$ and $\mathrm{CO}_{2}$. For every 10 unknown samples, in-house gelatin standards were run in duplicate; the gelatin standards are calibrated to the International Atomic Energy Agency (IAEA) reference materials USGS40 (L-glutamic acid, $\delta^{13} \mathrm{C}_{\mathrm{V}-\mathrm{PDB}}=-26.39 \%$ ), USGS41 (L-glutamic acid, $\delta^{13} \mathrm{C}_{\mathrm{V}-\mathrm{PDB}}=+37.63 \%$ ), IAEACH-6 (sucrose, $\delta^{13} \mathrm{C}_{\mathrm{V}-\mathrm{PDB}}=-10.45 \%$ ), USGS25 (ammonium sulfate, $\delta^{15} \mathrm{~N}_{\mathrm{AIR}}=-30.41 \%$ ), IAEA-N-1 (ammonium sulfate, $\delta^{15} \mathrm{~N}_{\mathrm{AIR}}=+0.43 \%$ ), and IAEA-N-2 (ammonium sulfate, $\delta^{15} \mathrm{~N}_{\mathrm{AIR}}=+20.41 \%$ ). Results are reported as per mil (\%) relative to the internationally accepted standards VPDB and AIR with $1 \sigma$ precisions of $\pm 0.2 \%$ and $\pm 0.3 \%$ for $\delta^{13} \mathrm{C}$ and $\delta^{15} \mathrm{~N}$, respectively.

For sulfur $\left(\delta^{34} \mathrm{~S}, \% \mathrm{~S}\right)$, analysis on subsamples of freeze-dried gelatin were undertaken by EA-IRMS at Iso-Analytical (UK). The reference material used for analysis was IA-R036 (Iso-Analytical working standard barium sulfate, $\delta^{34} \mathrm{~S}_{\mathrm{V}-\mathrm{CDT}}=+20.74 \%$ ). IA-R025 (Iso-Analytical working stan- 
dard barium sulfate, $\delta^{34} \mathrm{~S}_{\mathrm{V}-\mathrm{CDT}}=+8.53 \%$ ), IA-R026 (Iso-Analytical working standard silver sulfide, $\delta^{34} \mathrm{~S}_{\mathrm{V}-\mathrm{CDT}}=+3.96 \% 0$ ), and IA-R036 were used for calibration and correction of the ${ }^{18} \mathrm{O}$ contribution to the $\mathrm{SO}^{+}$ion beam. Results are reported as per mil (\%) relative to the IAEA reference materials IA-R061 (barium sulfate, $\delta^{34} \mathrm{~S}_{\mathrm{v}-\mathrm{CDT}}=+20.33 \%$ ), IAEA-SO-5 (barium sulfate, $\delta^{34} \mathrm{~S}_{\mathrm{V}-\mathrm{CDT}}=+0.5 \%$ ), and NBS-1577B (powdered bovine liver, $\delta^{34} \mathrm{~S}_{\mathrm{V}-\mathrm{CDT}}=+7.5 \%$ ). Results are reported as per mil (\%) with $1 \sigma$ precision of $\pm 0.2 \%$.

\section{RESULTS}

The results of the stable isotope and ${ }^{14} \mathrm{C}$ measurements on the 53 samples are presented in Table 1 for the Phnom Khnang Peung (KPP) site. The C:N ratios in the stable isotope results indicate bone protein preservation within the acceptable range parameters (i.e. 2.9-3.6; DeNiro 1985). The average ${ }^{13} \mathrm{C}$ value at $-18.4 \%$ for the humans, as well as in the pigs found as burial offerings, is slightly enriched, and we considered possible diet-induced ${ }^{14} \mathrm{C}$ offsets. The potential for freshwater ${ }^{14} \mathrm{C}$ reservoir effects are limited. The geology of the Cardamom Mountains is mainly Cambrian era siltstone and sandstone, with acid lithosoils (Crocker 1962), and there is just one minor and isolated geothermal feature in the northeastern ranges, which is not linked to any river or lake system. While the KPP site is at $630 \mathrm{~m}$ asl and at least $40 \mathrm{~km}$ from the sea, the appearance of maritime trade ceramics at the site (Beavan et al. 2012a,b) suggests trade connections with the Gulf of Thailand, and the exchange goods brought back by the Highland people could have included foods such as marine fish. Sulfur $\left(\delta^{34} \mathrm{~S}\right)$ can be an indicator of possible marine inputs, with terrestrial herbivores and omnivores ranging from $+4.4 \%$ to $+10 \%$ o $\delta^{34} \mathrm{~S}$, while fish and other animals in marine environs range between +16 and $+18 \%$ (Peterson and Fry 1987; Richards et al. 2003). At KPP, $\delta^{34} \mathrm{~S}$ values average only $+8.8 \%$ for both humans and pigs, indicating terrestrial sources of dietary sulfur. It is likely that the slightly enriched $\delta^{13} \mathrm{C}$ for humans is due to $\mathrm{C}_{4}$ plants in diets sourced from a tropical environment. This explanation is also supported by the results for pig, which may have been wild specimens that fed in the regional forest.

The AMS dates are conventional ${ }^{14} \mathrm{C}$ ages (Stuiver and Polach 1977), quoted according to the international standard set at the Trondheim convention (Stuiver and Kra 1986). The results have been calibrated with the internationally agreed curve for the Southern Hemisphere (SHCal13) of Hogg et al. (2013) using OxCal v 4.2 (Bronk Ramsey 1995, 1998, 2001, 2009). The use of the Southern Hemisphere curve follows recent research by Hua et al. (2004) and Sachs et al. (2009) that has identified a northward shift of the ITCZ in the period considered. The calibration curve has had an offset of $-21 \pm 6 \mathrm{yr}$ applied to account for mixing with the Northern Hemisphere (Q Hua, personal communication, 15 November 2011). The date ranges in Table 1 have been calculated using the maximum intercept method (Stuiver and Reimer 1986) and quoted with the endpoints rounded outward to $10 \mathrm{yr}$ where the errors are greater than or equal to $25 \mathrm{yr}$, and to $5 \mathrm{yr}$ where the errors are less than $25 \mathrm{yr}$. The probability distributions presented were obtained by the probability method (Stuiver and Reimer 1993). The chronological model (Figure 3) was constructed and run with OxCal v 4.2.

There was no stratigraphy between any of the dated jar burials, and so the model presented is simply an unordered group of dates with the assumption that they relate to a single, relatively continuous phase of burial activity. We also considered the extent of a lag time between primary and secondary mortuary treatments. While the individual burials are a secondary mortuary treatment, we are assuming the primary treatment of the bodies (excarnation by either open-air or shallow burial) were in favorable environmental conditions that could strip the body of flesh relatively rapidly. Natural biological processes are most active in a hot and humid environment in which a body might be expected to be fully defleshed within 3 months (Shattuck 2009). We also posit that bodies were likely wrapped to help contain the bones, as there is no differential loss of smaller bones (S Halcrow and 
S Ward, unpublished data), which would otherwise be expected if the body had been fully exposed to possible predator or environmental scattering. The lengths of mortuary rituals in Southeast Asia vary; ethnographic texts note that status and spiritual beliefs regarding death can influence the time between primary and secondary burial (Kickert 1960; Keyes 1975; Terwiel 1975; Anusaranasasanakiarti and Keyes 1980). However, we do not envisage this primary burial treatment occurring for an extended period of time, and perhaps less than a single year and no more than a few years elapsed between death, primary treatment, and reburial in the jars and coffins. Therefore, we believe that the ${ }^{14} \mathrm{C}$ ages, which relate to the deaths of the individuals, are suitable for estimating the timing of the observed burial practices.

In general, the ${ }^{14} \mathrm{C}$ ages from Phnom Khnang Peung fall within a 300-525 yr BP timeframe. The model (Figure 3) shows good agreement between the ${ }^{14} \mathrm{C}$ dates and the archaeological assumption that the burials are within one phase of activity $\left(\mathrm{A}_{\text {model }}=76\right)$.

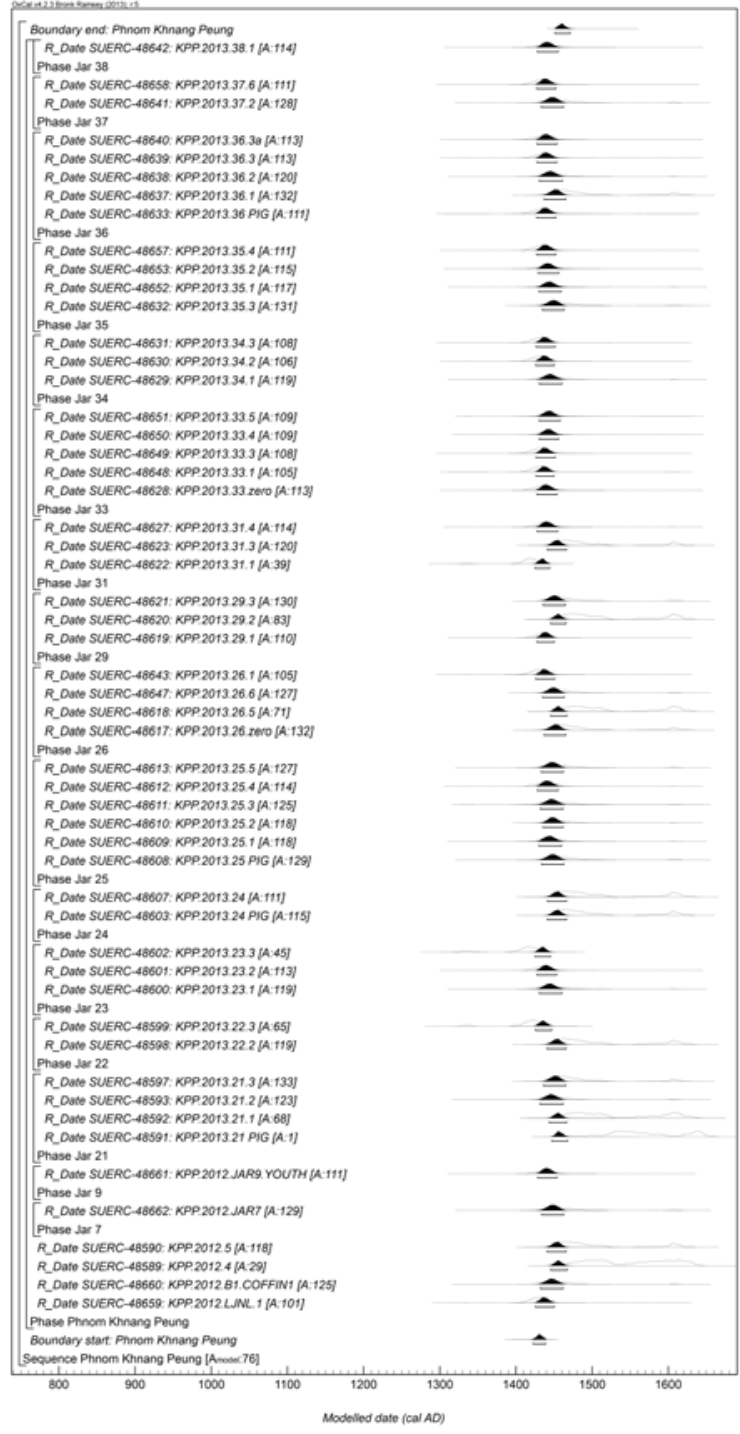

Figure 3 Chronological model of the ${ }^{14} \mathrm{C}$ dates from the burials at Phnom Khnang Peung (KPP). Each distribution represents the relative probability that an event occurred at some particular time. For each of the ${ }^{14} \mathrm{C}$ measurements, two distributions have been plotted, one in outline (the result of simple ${ }^{14} \mathrm{C}$ calibration) and one in solid black (based on the chronological model use). The other distributions correspond to aspects if the model. For example, 'start: Phnom Khnang Peung' is the estimated date that the burials began, based on the ${ }^{14} \mathrm{C}$ dating results. The large square brackets along with the $\mathrm{OxCal}$ keywords define the overall model exactly. 
${ }^{14}$ C Dates from Phnom Khnang Peung, Cambodia

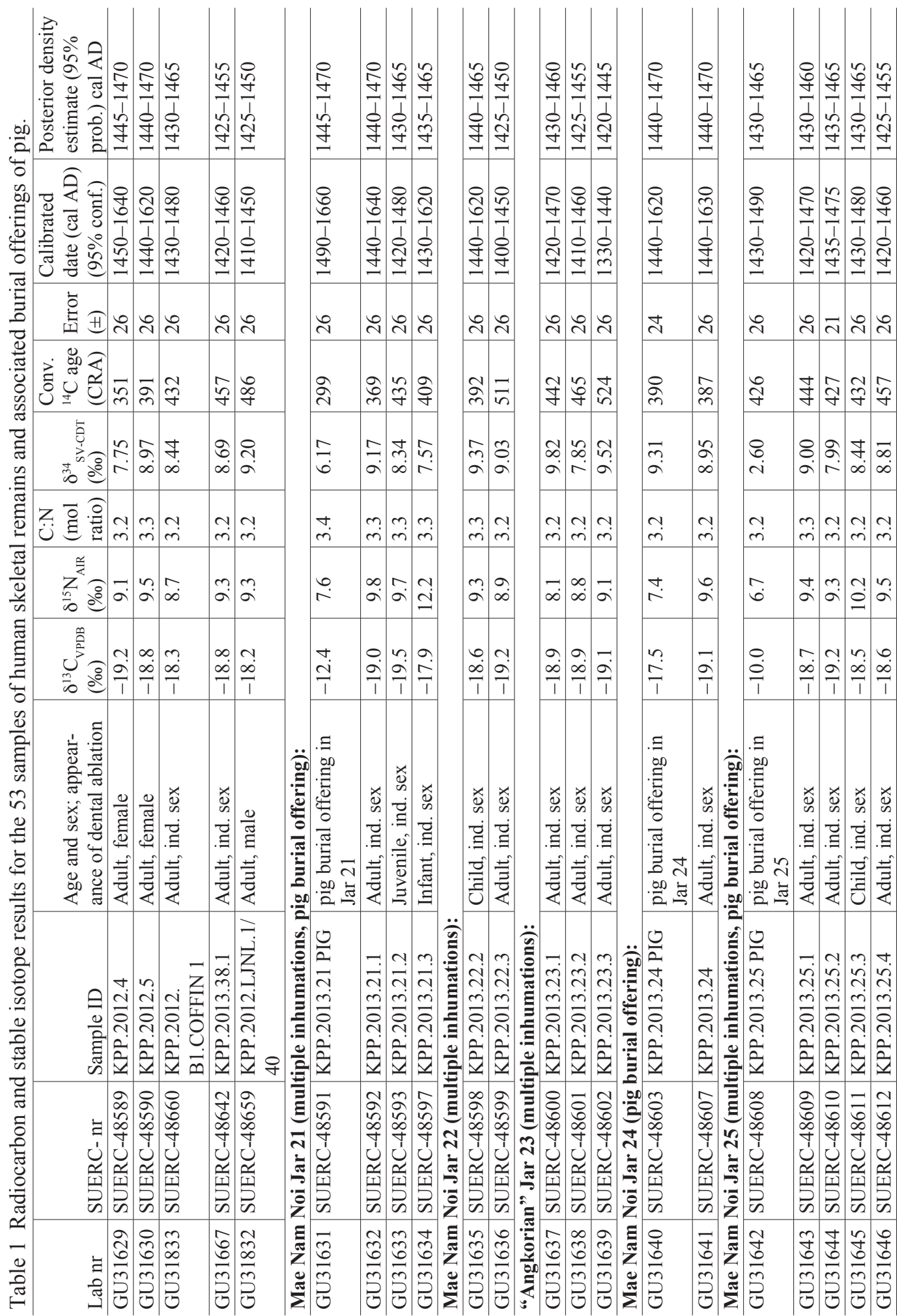


$N$ Beavan et al.

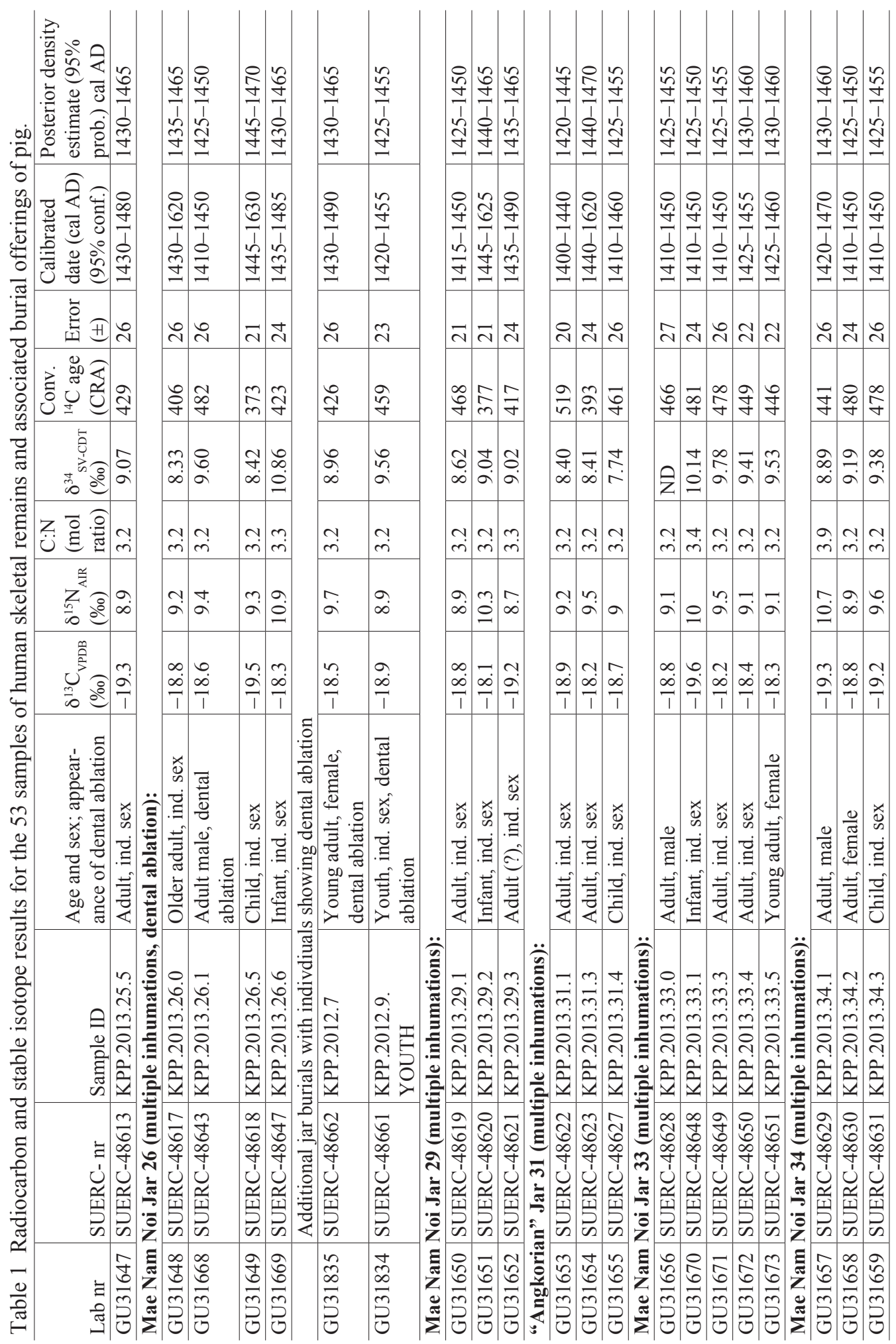



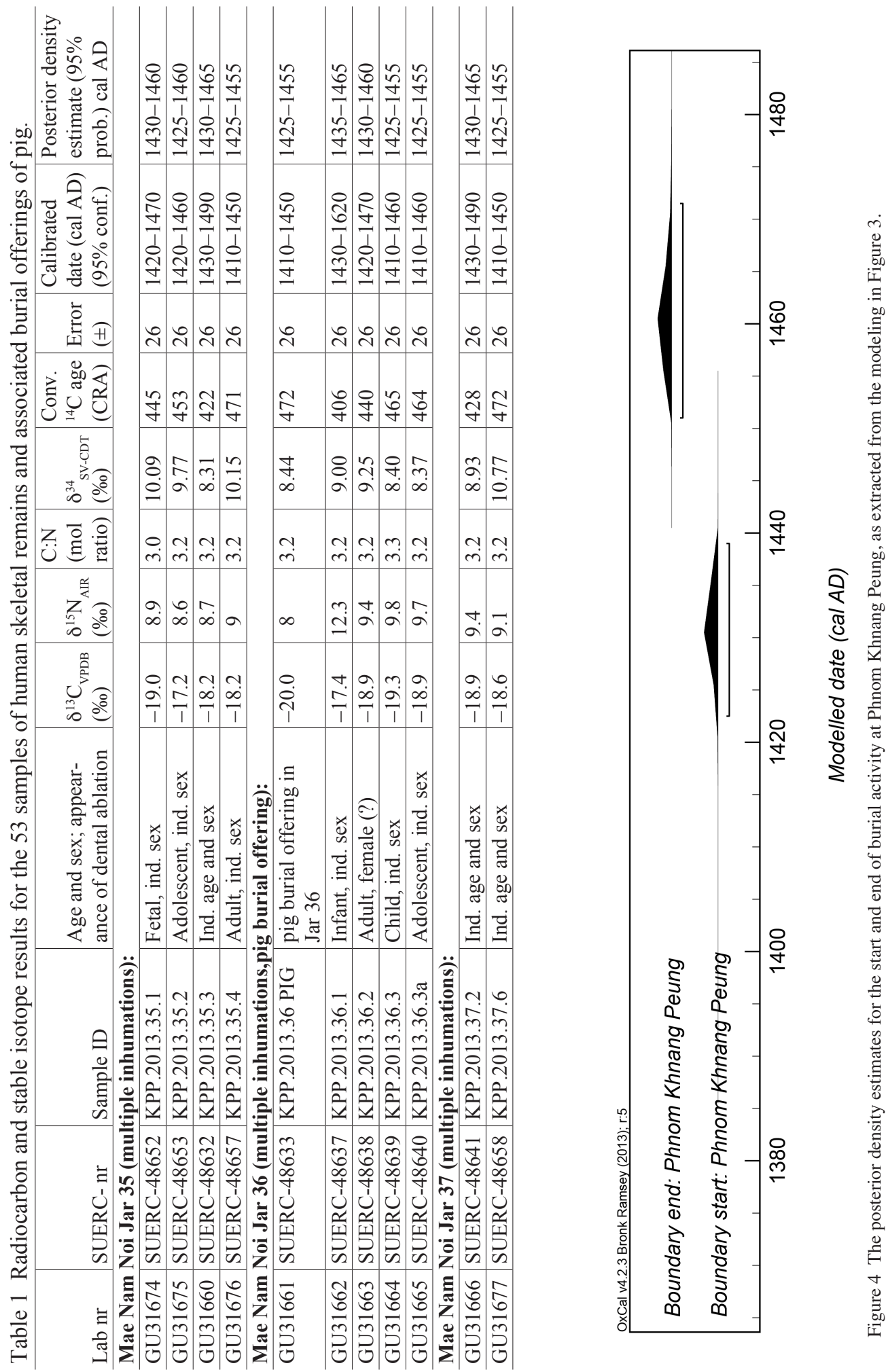
Of the $53{ }^{14} \mathrm{C}$ dates, only four (SUERC-48589, $-48591,-48602$, and -48622 ) have individual agreement indices below the acceptable threshold of 60 . This is not altogether unexpected, given both the number of dates ( 1 in 20 can be expected to be statistical outliers) and the overall short span of burial activity. Of the four dates with low individual agreements, SUERC-48591 raises some concern due to its very low agreement $(\mathrm{A}=1)$. While this date, or any of the other three, may be a statistical outlier, their inclusion in the model does not make the overall agreement fall below 60 . This model is preferred over using any form of outlier analysis, formal or subjective, as it produces a more conservative estimate. However, it should be noted that formal Bayesian outlier analysis was performed on the data and the results are virtually identical, suggesting that this model is not importantly wrong.

The model estimates that burial activity began in cal AD 1420-1440 (95\% probability; Figure 4; start: Phnom Khnang Peung) and probably in cal AD 1425-1440 (68\% probability). The burials spanned 15-45 years (95\% probability; Figure 6; span: Phnom Khnang Peung) and probably $20-40$ years (68\% probability). Burials at this site ended in cal AD 1450-1475 (95\% probability; Figure 4; end: Phnom Khnang Peung) and probably in cal AD 1450-1465 (68\% probability).

\section{TIMING OF SPECIFIC PHENOMENA}

\section{Angkorian Jar burials}

One aspect of the conformity of the Jar Burial mortuary ritual across all of the Cardamom sites is that the human remains were placed in Mae Nam Noi/Singburi ceramic jars (Figure 5a). These large ceramic storage jars made up maritime-trade cargoes on ships plying the Gulf of Thailand from the 14th century AD (Brown 1977; Beavan et al. 2012b). The exception to the collections of Mae Nam Noi ceramic jars is the appearance of a non-maritime trade ceramic jar style, generalized as "Angkorian" (Figure 5b). Previous to work at the KPP site, only one Angkorian ceramic jar had ever been found in each of the Cardamom Jar Burial sites surveyed. The Angkorian jar is similar in size to the Mae Nam Noi ( $\sim 63 \mathrm{~cm}$ in height). It is typical of production from the Buriram kilns of northeast Thailand's Khorat Plateau, near the modern border of Cambodia and Thailand. The Buriram kilns were associated with ceramic production within the Angkor kingdom from the 11th to 13th centuries AD (Groslier 1981). It is also possible these jars were from the 12th to early 15th century AD Torp Chey kiln sites, which contributed to Angkorian ceramic production and inland trade systems of the period (Hendrickson 2008; Cort and Lefferts 2013; Ea 2013). While Courbin (1988) reported on a small, squat form of an Angkorian era jar being used for the in-ground burial of cremated remains at the site of Sras Srang in the 11th century and possibly the 15th century AD, we have never encountered any previous instance of an Angkorian jar being used for the burial of human remains in any of the Cardamom jar burial sites, but cannot discount the possibility that this was due to poor bone preservation.

At Phnom Khnang Peung, three Angkorian jars were found, and two of these jars held human remains (multiple burials within Jar 23 and Jar 31; Table 1). This is a first use of Angkorian jars for the burial of human remains. The earliest dated Angkorian jar burial occurred in cal AD 1420-1440 (95\% probability; Figure 7; earliest Angkor jar burial), and probably in cal AD 1425-1440 (68\% probability). The latest dated Angkor jar burial occurred in cal AD 1440-1465 (95\% probability; Figure 7; latest Angkor jar burial), and probably in cal AD 1445-1460 (68\% probability). The span of the Angkor jar burials was 5-40 years (95\% probability; Figure 6; span Angkor jar burial), and probably $10-30$ years (68\% probability). Two individuals buried within the Angkorian jars (KPP.2013.23.3 adult male, and KPP.2013.31.1, adult of indeterminate sex; SUERC-48602, SUERC-48622; Table 1) are among the oldest of the burials at KPP, with posterior density estimates of cal AD 1420-1445 (95\% probability). 

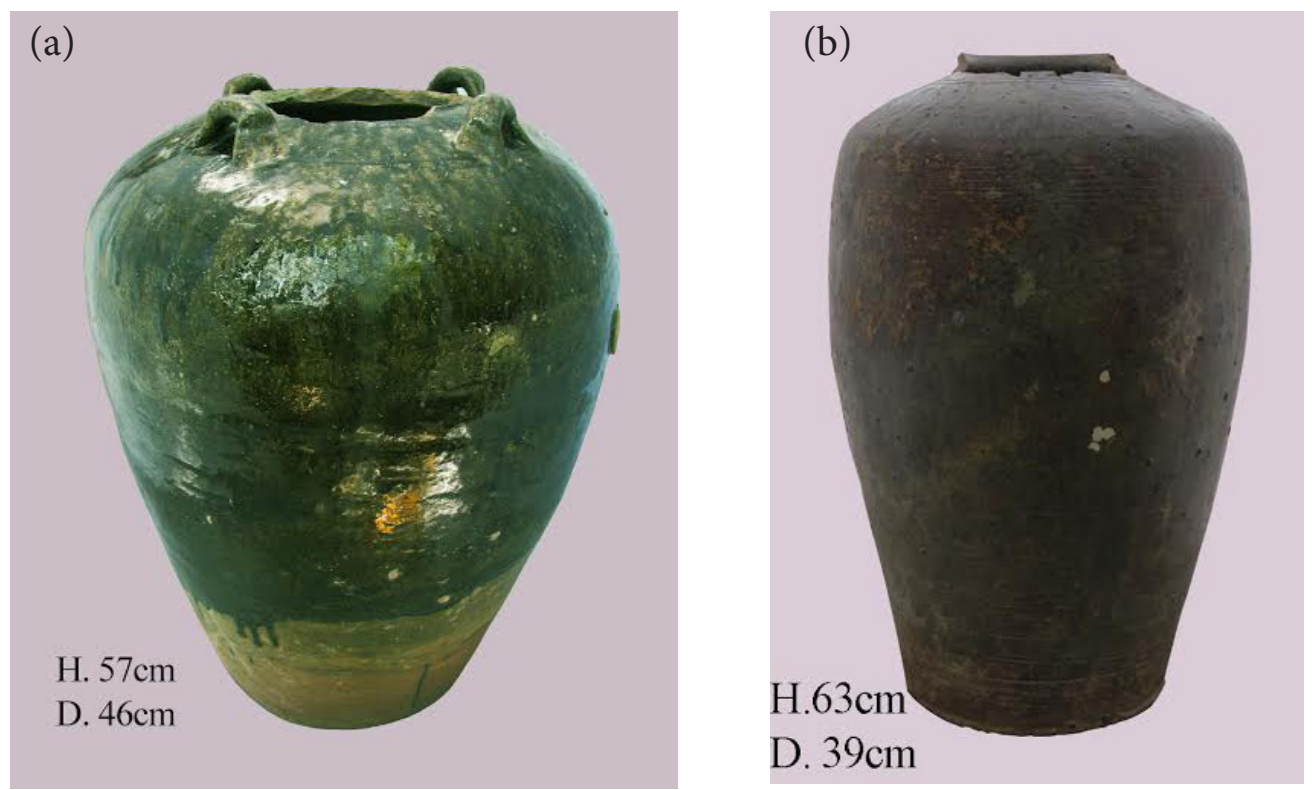

Figure 5 A typical Mae Nam Noi storage jar from the Phnom Khnang Peung site (a) and an "Angkorian” storage jar (b)

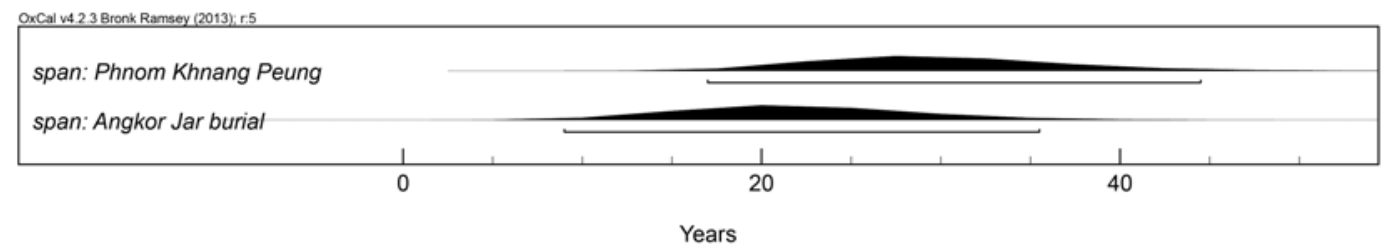

Figure 6 Span of activity associated with the overall burial activity at the site (span: Phnom Khnang Peung) and more specifically with the Angkor jars (span Angkor jar burial). The spans are derived from the chronological modeling in Figure 3.

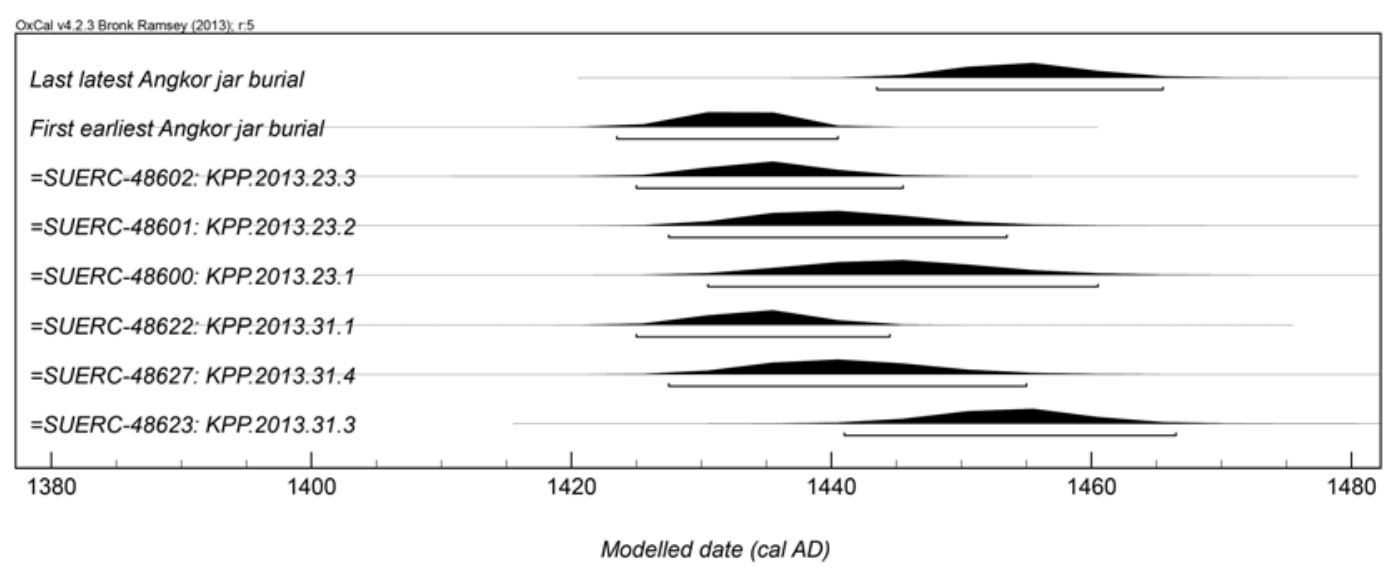

Figure 7 Posterior density estimates for the burials in Angkor jars. OxCal was used to calculate the earliest and latest probability for these burials, and the difference between the two was used to calculate the span of Angkor jar burial activity at Phnom Khnang Peung (Figure 6). 


\section{Animal Offerings within the Burial Jars}

There were eight jar burials that also contained skeletal elements of a pig or a dog along with the human remains. No entire skeleton of the given animal was ever present. We have not found faunal remains with Jar and Coffin burials at other Cardamom Mountain sites. We present the ${ }^{14} \mathrm{C}$ dating of four samples of pig remains found associated with human remains; additional dating of faunal remains found as apparent burial offerings is now underway to add to our understanding of the temporality and possible meanings of faunal offerings in the Cardamom Jar Burial ritual.

Posterior density estimates of date ranges for the four pig samples from the overall Bayesian modelling indicate the earliest pig offering is cal AD 1425-1455 (95\% probability; SUERC-48633) and the latest pig offering is cal AD 1445-1470 (95\% probability; SUERC-48591; Table 1). We cannot assess at present whether the presence of faunal remains in one jar and not another is indicative of a significant difference in the burial ritual for one or more of the people within a particular jar. The meanings of faunal remains in burial assemblages are open to different interpretations (cf. Morris 2008,2011 ), and we considered other indications that certain burials are special, such as the variation in the number and/or types of associated glass bead burial goods in burial jars holding faunal remains. We found that the human burials accompanied by faunal remains did not have different burial goods or quantity of same, compared to human burials unaccompanied by faunal remains (A K Carter and N Beavan, unpublished data).

\section{Coffin Burials}

In Beavan et al. (2012a), the collection of 12 coffins fashioned from whole logs at Phnom Pel had well-defined growth-ring structures and minimal carving away of outer layers. For the Phnom Pel coffin collection, it was assumed that the outermost ring layer likely represented sapwood suitable for ${ }^{14} \mathrm{C}$ dating of the time of tree harvest for coffin construction. At KPP, three entire coffins and many fragments of perhaps up to three additional coffins were discovered. Each of the coffins found at the KPP site are remarkable for their singular styles, with no two coffins alike at the site. However, all of the styles employed a severe shaping of the coffin — including straight-sided box forms and one elongated "pod"-shaped coffin. Unfortunately, this severe shaping of the harvested logs for coffin construction eliminated the possibility for sampling relevant outermost growth rings for a reliable ${ }^{14} \mathrm{C}$ age to obtain a direct date on the KPP site coffins. The only date available relating to the use of coffins in the KPP site is for bone from an adult of indeterminate sex (KPP.2012.B1.COFFIN 1), and dated to cal AD 1430-1465 (95\% probability; SUERC-48660; Table 1). This date represents a coffin burial toward the end of site use, with respect to the overall Bayesian modeling of burials ending in cal AD 1450-1475 (95\% probability; Figure 3; end: Phnom Khnang Peung).

\section{Dental Ablation}

At KPP, seven adult individuals were identified with remodeled alveolar bone indicative of the antemortem loss of the maxillary lateral incisors and canines. The consistent bilateral absence of these teeth in these individuals suggests the use of dental modification at Phnom Khnang Peung (S Halcrow and S Ward, unpublished data). We have now dated three of the seven individuals showing dental ablation. The posterior density estimates (95\% probability) for the three dated burials with dental ablation at KPP are KPP2012.7, a female young adult, cal AD 1430-1465 (SUERC-48662); KPP 2012.9 Youth, indeterminate sex, cal AD 1425-1455 (SUERC-48661); and KPP2013.26.1, an adult male, cal AD 1425-1450 (SUERC-48643) (Figures 3, 8).

Dental ablation practices are recorded in a number of prehistoric sites in Southeast Asia. For example, Tayles (1996) reports on the ablation of maxillary lateral incisors in the prehistoric site of Khok 
Phanom Di (4000-3500 yr BP) in Thailand. Intentional dental modification, in the form of ablation and filing, was also previously reported in Cambodia at Krasang Thmey ( 2050-1660 yr BP; Domett 2005), and at two late Iron Age sites (Phum Snay and Phum Sophy, 2500-1500 yr BP; Domett et al. 2011). There appears to be no other historical or archaeological evidence for the continuation of dental ablation in the time between the late Iron Age at Phum Snay and Phum Sophy, and the 15 th century AD evidence for dental ablation in the Cardamom Mountain burial ritual. Dental modification among modern Cambodian highland peoples is only briefly noted at the turn of the 20th century AD, by the French diplomat and ethnologist Adhémar Leclère (1853-1917). Leclère reported on a practice among northeastern Cambodia's Mondalkiri highlanders involving the removal of upper and lower canine teeth with a sharp knife, in both boys and girls from about 10 or 11 yr of age (Tranet 2002:62). A paper presenting a detailed review of dental ablation in prehistoric and historic Southeast Asia and results of the prevalence and patterns of dental ablation from Phnom Khnang Peung and its possible cultural meanings is in preparation.

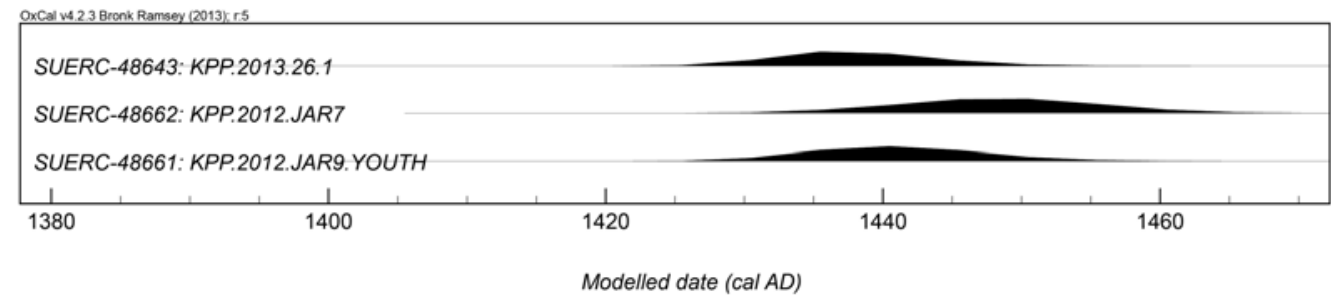

Figure 8 Posterior density estimates for the three dated burials at Phnom Khnang Peung with dental ablation, as extracted from the modeling in Figure 3.

\section{DISCUSSION}

Very little is known about the culture that practiced the Jar and Coffin Burial ritual in the Cardamom Mountains. Our presentation here of the dating and Bayesian treatment of the ${ }^{14} \mathrm{C}$ results from KPP represents the most extensive data set on the Jar and Coffin Burial ritual thus far assembled by the "Living in the Shadow of Angkor" project, which aims to build an understanding of a highland people who were previously only shadows in the Cambodian archaeological record. As well as extending the chronological record of the Cardamom sites first presented in Beavan et al. (2012a), we present some newly observed features for the Jar and Coffin mortuary ritual, including human burials within Angkorian jars, animal remains accompanying some human burials, and evidence of a cultural practice of dental ablation. These discoveries provide new insights about the values and beliefs of this Highland culture.

As no ancient settlements associated with Highland peoples have yet been found in the deep jungle of the Cardamoms, the only evidence thus far discovered of these Highlanders is in their mortuary ritual. But mortuary populations provide an important source of cultural evidence. Interactions of the living with the dead in a mortuary ritual, such as the treatment of the remains and the emplacement and type of burial goods ("exchanges"; Venebrux 2007:5) allow us to hypothesize about the values of that society (Barraud et al. 1994; Venebrux 2007), as mortuary rituals express a culture's values and notions of self (Metcalf and Huntington 1991). Therefore, specific phenomena found at KPP may infer something of the cultural values and beliefs of the people who interred their dead in these remote mountain ledges.

The Phnom Khnang Peung Jar Burial site holds up to 152 interments in 40 burial jars and a coffin. The mortuary population includes both males and females, with infants, subadults, adults, and at least one aged adult represented (S Halcrow and S Ward, unpublished data). 
As mentioned previously, direct dating of sapwood could not be performed for the log coffins at KPP. Coffin 1 from section B (Figure 2c) was the only coffin that contained human bone remains, which dated to cal AD 1430-1465 (95\% probability; SUERC-48660). The date range indicated a later burial with respect to the overall date range for site use (Figure 4).

One aspect of the overall chronological record of KPP that is especially intriguing is the relatively short time span of burial activity, given that it is by far the largest of all the known Jar and Coffin burial sites. Phnom Khnang Peung burial activity spanned only $15-45$ years (95\% probability; Figure 6; span: Phnom Khnang Peung) and probably 20-40 yr (68\% probability). We compare this rather short span for KPP site use with the span of the burial activity at Phnom Pel, the second largest Jar and Coffin burial site. The Phnom Pel site was hampered by poor bone preservation, with only seven ${ }^{14} \mathrm{C}$ ages produced for human remains (Beavan et al. 2012a:9). A more robust span for an aspect of the ritual (i.e. the harvesting of the logs for coffin construction) was drawn from the direct dating of the 12 Phnom Pel coffins, which spanned 55-215 years (95\% probability and probably 70-130 years (68\% probability; Figure 9 of Beavan et al. 2012a). Could health have been the cause for the comparatively short, intense concentration of burial activity at KPP? Halcrow et al. (2014) have recently reported on the first bioarchaeological evidence for scurvy in a 6-yr-old child from KPP. Additional evidence of anemia in this individual could suggest that metabolic disease may be linked to malaria or parasitic infections (Halcrow et al. 2014). A full review of the overall health characteristics of the mortuary population in this site is underway.

The discovery of possible dental modification in the KPP population lends insight about cultural practices of the Jar and Coffin burial people. It appears to be the first indication of dental modification in an archaeological highland population of the region in the 15th century. A fuller presentation of the prevalence and patterns of dental ablation from KPP and its possible cultural meanings is in preparation.

Our discovery of two Angkorian jars with human remains at KPP challenges us to further consider the meaning of these vessels and their significance in the mortuary ritual. As previously noted, we have found only a single Angkorian jar among the assemblages of Mae Nam Noi jars in every other Jar and Coffin burial site (Beavan et al. 2012a). At KPP, the earliest date range for these burials is cal AD 1420-1445 (95\% probability; SUERC-48602 and-48622; Table 1) and indicates that Angkorian jars were used for some of the earliest burials at the site. What is the significance of the use of Angkorian jars? Venebrux (2007:5) noted that introduced goods attain a kind of status and often become items of mortuary "exchange," i.e. the gifts of the living to the dead. Like the choice of the Mae Nam Noi and other maritime trade ware used in the ritual, the presence and utilization of the Angkorian jars for the burial ritual intimates these objects had a specific value and meaning, and that their acquisition was important. The occurrence of burials within the Angkorian jars thus suggests some still to be discovered significance in the choice of these ceramics. The dating from human remains within the jars also provides a terminus ante quem for acquisition of these ceramics, which may help us in discovering the connection between the Highlanders and the lowland Angkorian ceramic trade system in the 15th century AD (Hendrickson 2008; Cort and Lefferts 2013; Ea 2013).

We have also, for the first time, found burials of pig and dog with the human remains in a Jar and Coffin burial site. Although the interpretation of animal deposits in burials is open to debate (Morris 2008,2011 ), we suggest that the quite deliberate placements of the faunal material within certain burial jars may be burial offerings. We cannot say if the pigs and dogs found within the burials were domesticated or wild species. The remains may come from hunting; the Cardamom Mountains are populated by both the wild dog (dohle, Cuon alpinus) and wild boar (Sus scrofa). We have consid- 
ered whether the presence of pig and dog may be associated with the status of a particular human burial. However, the number or type of other grave goods, such as the copper alloy rings and varied glass beads, in any of the jars with animal burials do not provide indications of different status for these particular jars (A K Carter and N Beavan, unpublished data). The chronology we can develop from the available pig bone results does suggest that the practice was in place throughout the span of the burial activity at the site. The date ranges for posterior density estimates for four pig samples from the overall Bayesian modeling indicate the earliest pig offering is cal AD 1425-1455 (95\% probability; SUERC-48633) and the latest pig offering is cal AD 1445-1470 (95\% probability; SUERC-48591; Table 1). Additional dating of faunal remains and the determination of pig and dog subspecies is now underway to add to our understanding of the temporality and possible meanings of faunal remains in the Cardamom Jar Burial ritual.

The corpus of ${ }^{14} \mathrm{C}$ analyses from KPP presented here have appreciably enhanced our understanding of a 15-17th century AD Highland burial practice in the Cardamom Mountains of Cambodia, which was first described in Beavan et al. (2012a). The discovery of previously unknown variations in the Jar and Coffin burial practice - the use of Angkorian jars for burials, the inclusion of faunal remains with some burials, and the first evidence for the practice of dental ablation in this Highland culture - was aided by its large mortuary sample and a good state of bone preservation in KPP, relative to other Jar and Coffin burial sites. Phnom Khnang Peung thus stands as a prime exemplar of the Jar and Coffin burial culture of the Cardamom Mountains, and provides significant new information to more fully develop our narration of a Highland people living in the Late- to Post-Angkorian period.

\section{ACKNOWLEDGMENTS}

The "Living in the Shadow of Angkor" Project is funded by the Royal Society of New Zealand Marsden Fund (Beavan NR, Contract \#UUOO-1211) and University of Otago Performance Based Research Funding (Beavan 10817001SLA). The Ministry of Culture and Fine Arts (MoCFA) of the Royal Cambodian government assisted with permits and administrative support, and we especially acknowledge the field assistance of Mr. Ouck Sokha (MoCFA). Metal artifact analyses was provided by Prof Dr Ernst Pernicka, Curt-Engelhorn-Zentrum Archäometrie gGmbH an der Universität Heidelberg. We also wish to thank Prof Gordon Cook of the Scottish Universities Environmental Research Centre (SUERC) for his generosity and assistance to our ${ }^{14} \mathrm{C}$ dating program, and Mr Robert McPhee (Otago School of Medicine) for graphic Figures. We acknowledge contributions by Dr Sian Halcrow (Department of Anatomy, Otago School of Medical Sciences) and Ms Stacey Ward (independent contractor) for their edits of the text and citations.

\section{REFERENCES}

Anusaranasasanakiarti PK, Keyes CF. 1980. Funerary rites and the Buddhist meaning of death: an interpretive text from northeast Thailand. Journal of the Siam Society 68:1-28.

Barraud C, De Copet D, Iteanu A, Jamous R. 1994. Of Relations and the Dead: Four Societies Viewed from the Angle of Their Exchanges. Oxford: Berg.

Bayliss A. 2009. Rolling out revolution: using radiocarbon dating in archaeology. Radiocarbon 51(1):123-47.

Beavan N, Halcrow S, McFadgen B, Hamilton D, Buckley B, Tep S, Shewan L, Sokha O, Fallon S, Miksic J, Armstrong R, O'Reilly D, Domett K, Chhem KR. 2012a. Radiocarbon dates from jar and coffin burials of the Cardamom Mountains reveal a unique mortuary ritual in Cambodia's Late- to Post-Angkor period (15th-17th centuries AD). Radiocarbon 54(1):1-22.
Beavan N, Tep S, Zoppi U, McCarthy B, Schilling M, Cort L, Lu SF. 2012b. Field note: a radiocarbon date for the Koh S'dech shipwreck, Koh Kong Province, Kingdom of Cambodia. Freer Sackler Gallery, SEA Ceramics Library, Smithsonian Institution. Washington, DC. Available at http://seasianceramics.asia. si.edu/resources/essay.asp?id=218.

Bellwood PJ. 2007. Prehistory of the Indo-Malaysian Archipelago. Canberra: ANU E-Press.

Bronk Ramsey C. 1995. Radiocarbon calibration and analysis of stratigraphy: the $\mathrm{OxCal}$ program. Radiocarbon 37(2):425-30.

Bronk Ramsey C. 1998. Probability and dating. Radiocarbon 40(1):461-74.

Bronk Ramsey C. 2001. Development of the radiocarbon calibration program. Radiocarbon 43(2A):355-63. 
Bronk Ramsey C. 2009. Bayesian analysis of radiocarbon dates. Radiocarbon 51(1):337-60.

Brown R. 1977. The Ceramics of South-East Asia: Their Dating and Identification. Kuala Lumpur: Oxford University Press.

Brown R. 2004. The Ming Gap and shipwreck ceramics in Southeast Asia [PhD dissertation]. Department of Art History, University of California, Los Angeles.

Buck CE, Cavanagh WG, Litton CD. 1996. Bayesian Approach to Interpreting Archaeological Data. Chichester: John Wiley \& Sons.

Buikstra JE, Ubelaker DH. 1994. Standards for Data Collection from Human Skeletal Remains. Fayetteville: Arkansas Archaeological Survey.

Chia S, Koon P. 2003. Recent discovery of ancient log coffin in Semporna, Sabah. Sabah Society Journal 20:35-43.

Cort L, Lefferts L. 2013. Jars in the central highlands of mainland Southeast Asia. In: Klokke M, Degroot V, editors. Materializing Southeast Asia's Past: Selected Papers from the 12th International Conference of the European Association of Southeast Asian Archaeologists. Volume 2. Singapore: NUS Press. p 233-41.

Courbin P. 1988. La fouille du bassin du Sras Srang. In: Dumarcay J, editor. Documents graphiques de la Conservation d'Angkor, 1963-1973. École française d'Extrême-Orient 18:21-44.

Crocker CD. 1962. Exploratory Survey of the Soils of Cambodia. Phnom Penh: Royal Cambodian Government Soil Commission and USAID.

Deniro MJ. 1985. Postmortem preservation and alteration of in vivo bone collagen isotope ratios in relation to palaeodietary reconstruction. Nature 317(6040):806-9.

Domett KM. 2005. The Skeletal Remains from Krasaing Thmei, Banteay Meachey Province, Cambodia. Townsville: James Cook University.

Domett KM, Newton J, O'Reilly DJW, Tayles N, Shewan L, Beavan N. 2011. Cultural modification of the dentition in prehistoric Cambodia. International Journal of Osteoarchaeology 23(3):274-86.

Ea D. 2013. Angkorian stoneware ceramics along the east road from Angkor to Bakan at Torp Chey Village. Udaya 11:59-98.

Fox RB. 1970. The Tabon Caves. Monograph 1. Manila: National Museum.

Grave P, Maccheroni M. 2009. Characterizing Asian stoneware jar production at the transition to the early Modern period, 1550-1650. In: McCarthy B, Salzman-Chase E, Cort LA, Douglas JG, Jett P, editors. Scientific Research on Historic Asian Ceramics. Proceedings of the Fourth Forbes Symposium at the Freer Gallery of Art. London: Archetype Publications. p 110.

Groslier BP. 1981. Introduction to the ceramic wares of Angkor. In: Stock D, editor. Khmer Ceramics 9th$14^{\text {th }}$ Century. Singapore: Oriental Ceramics Society.

Halcrow SE, Harris NJ, Beavan N, Buckley HR. 2014. First bioarchaeological evidence of probably scurvy in Southeast Asia: multifactorial etiologies of vitamin $\mathrm{C}$ deficiency in a tropical environment. International Journal of Paleopathology 5:63-71.

Harris P. 2007. Zhou Daguan: A Record of Cambodia, the Land and Its People. Chiang Mai: Silkworm Books.

Harrisson T. 1974. Early 'jar burials' in Borneo and elsewhere. Asian Perspectives 17(2):141-4.

Hendrickson M. 2008. New evidence of brown glaze stoneware kilns along the east road from Angkor. Bulletin of the Indo-Pacific Prehistory Association 28:52-6.

Higham C. 2002. Early Cultures of Mainland Southeast Asia. Bangkok: River Books.

Hogg AG, Hua Q, Blackwell PG, Niu M, Buck CE, Guilderson TP, Heaton TJ, Palmer JG, Reimer PJ, Reimer RW, Turney CSM,Zimmerman SRH. 2013. SHCal13 Southern Hemisphere calibration, 0-50,000 years cal BP. Radiocarbon 55(4):1889-903.

Hua Q, Barbetti M, Zoppi U, Fink D, Watanasak M, Jacobsen GE. 2004. Radiocarbon in tropical tree rings during the Little Ice Age. Nuclear Instruments and Methods in Physics Research B 223-224:489-94.

Keyes CF. 1975. Tug of war for merit: cremation of a senior monk. Journal of the Siam Society 63:44-62.

Kickert R. 1960. A funeral in Yang-Terng, Changwat Ubon, northeast Thailand. Journal of the Siam Society 48:73-83.

Kurjack EB, Sheldon CT. 1971. The urn burial caves of Southern Cotobato, Mindanao, Philippines. Silliman Journal 18:127-53.

L'Abbe EN. 2005. A case of commingled remains from rural South Africa. Forensic Science International 151:201-6.

Longin R. 1971. New method of collagen extraction for radiocarbon dating. Nature 230(5291):241-2.

Metcalf P, Huntington R. 1991. Celebrations of Death: The Anthropology of Mortuary Ritual. 2nd edition. Cambridge: Cambridge University Press.

Morris J. 2008. Associated bone groups: one archaeologist's rubbish is another's ritual deposition. In: Davis $\mathrm{O}$, Waddington $\mathrm{K}$, Sharples N, editors. Changing Perspectives on the First Millenium BC. Oxford: Oxbow Books. p 83-98.

Morris J. 2011. Investigating Animal Burials: Ritual, Mundane and Beyond. British Archaeological Reports, British Series 535. Oxford: Archaeopress.

Naysmith P, Cook G, Freeman S, Scott EM, Anderson R, Dunbar E, Muir G, Dougans A, Wilcken K, Schnabel C, Russell N, Ascough P, Maden C. $2010 .{ }^{14} \mathrm{C}$ AMS at SUERC: improving QA data from the 5MV tandem AMS and 250kV SSAMS. Radiocarbon 52(2):263-71.

Pelliot P. 1903. 'Le Fou-nan.' Bulletin de l'Ecole Française d'Extrême-Orient 3(2):248-303.

Peterson BJ, Fry B. 1987. Stable isotopes in ecosystem studies. Annual Review of Ecological Systems 18:293-320.

Richards MP, Fuller BT, Sponheimer M, Robinson T, Ayliffe L. 2003. Sulfur isotopes in paleodietary stud- 
ies: a review and results from a controlled feeding experiment. International Journal of Osteoarchaeology 13:37-45.

Sachs JP, Sachse D, Smittenberg RH, Zhang Z, Battisti DS, Golubic S. 2009. Southward movement of the Pacific intertropical convergence zone AD 1400 1850. Nature Geoscience 2:519-25.

Sayavongkhamdy T, Bellwood P. 2000. Recent archaeological research in Laos. The Melaka Papers, Volume 3. Bulletin of the Indo-Pacific Prehistory Association 19:101-10.

Schroeder S. 2001. Secondary disposal of the dead: cross-cultural codes. World Cultures 12(1):77-93.

Shattuck C. 2009. An analysis of decomposition rates on outdoor surface variations in Central Texas. Theses and Dissertations-Anthropology. https://digital.library.txstate.edu/handle/10877/4068.

Stark MT. 2001. Some preliminary results of the 19992000 archaeological field investigations at Angkor Borei, Takeo Province. Udaya 2:19-31.

Stuiver M, Kra RS. 1986. Editorial comment. Radiocarbon 28:ii.

Stuiver M, Polach HA. 1977. Discussion: reporting of ${ }^{14} \mathrm{C}$ data. Radiocarbon 19(3):355-63.

Stuiver M, Reimer PJ. 1986. A computer program for radiocarbon age calibration. Radiocarbon 28(2B):1022-30.
Stuiver M, Reimer PJ. 1993. Extended ${ }^{14} \mathrm{C}$ data base and revised CALIB $3.0{ }^{14} \mathrm{C}$ calibration program. Radiocarbon 35(1):215-30.

Tayles N. 1996. Tooth ablation in prehistoric Southeast Asia. Internationd Journal of Osteoarchaeology 6(4):333-45.

Tep S. 2014. Discovery of ceramics from the Koh Sdach shipwreck, Koh Kong province, Cambodia. In: Proceedings of the 2014 Asia-Pacific Regional Conference on Underwater Cultural Heritage, 12-16 May 2014, Honolulu, Hawai' $i$. http://www.themua.org/ collections/files/original/8e6a09403f2653f2ed38e3fabf672c93.pdf.

Terwiel BJ. 1975. Monks and Magic: An Analysis of Religious Ceremonies in Central Thailand. London: Curzon Press.

Tranet M. 2002. Les Proto-Khmer du Cambodge. Phnom Penh: Atelier d Ímpression Khmere. 115 p.

Vandeputte K, Moens L, Dams R. 1996. Improved sealed-tube combustion of organic samples to $\mathrm{CO}_{2}$ for stable isotope analysis, radiocarbon dating and percent carbon determinations. Analytical Letters 29(15):2761-73.

Venebrux E. 2007. Robert Hertz's seminal essay and mortuary rites in the Pacific region. Journal de la Société des Océanistes 124:5-10. 